\title{
Viability of BCD Funeral Homes in Bacolod City
}

\author{
Lyndee D. Granada \\ University of Negros Occidental-Recoletos, Bacolod City, Philippines \\ lyndeegranada0816@gmail.com \\ https://orcid.org/0000-0001-7695-9224
}

\begin{abstract}
This quantitative study determined and assessed the viability of $B C D$ funeral homes in Bacolod City, Philippines. BCD Funeral Homes is a newly established branch offering funeral services to the people. Utilizing a descriptive research design, data were gathered from 82 respondents composed of 32 employees and 50 customers using researcher-made instruments. The study revealed that the employees perceived the company as viable. Moreover, the competitors are the main challenge of the company, while its opportunity includes the improvement of services by offering cremation in the future. Furthermore, the company's corporate social responsibility programs include programs for the indigents, proper waste disposal, observance of proper hygiene and sanitation, compliance with the Department of Environment and Natural Resources, and government regulations. In addition, the company's six months' financial performance yielded a loss since the company is just starting. Nevertheless, the feasibility study proved that the business is profitable and, thus, viable.
\end{abstract}

Keywords: Business Management, Business, Viability, Financial Performance, Descriptive, Bacolod City, Philippines 